\title{
STUDI TEKNIK TRADISIONAL BUDIDAYA DAN PRODUKSI KENANGA JAWA (Cananga odorata f. macrophylla) DI BLITAR
}

\author{
Study of Cultivation Traditional Technical and Production Java Kenanga (Cananga odorata f. \\ Macrophylla) in Blitar
}

Hariadi Propantoko $^{1 *}$, Irdika Mansur ${ }^{2}$, Arum Sekar Wulandari ${ }^{2}$

(Diterima Agustus 2018/Disetujui November 2020)

\begin{abstract}
Java kenanga or kenanga (Cananga odorata f. macrophylla) is a tropical and sub-tropical tree species that grows naturally in Indonesia and produces essential oil. This species has been cultivated in the past by community in Indonesia, mainly on their yard. The population of kenanga has decreased significantly, but in Blitar district the community is still doing cultivating the species although in a small scale. The purpose of this research is to observe the cultivation efforts by the community and also kenanga flower production in Blitar district. This research was conducted by interviewing farmers and observation of kenanga trees in the field. The results showed that cultivation efforts being made to improve the production of kenanga flower is by pruning, fertilizing, flowering routine and retrieval or emoval of kenanga fruit. The average kananga flower production reached $381 \mathrm{~kg} /$ year / tree in the age group above 11 years. Factors that affect flower production were tree age (years), total tree height $(\mathrm{m})$, diameter at breast height $(\mathrm{cm})$ and the width tree canopy $\left(\mathrm{m}^{2}\right)$. The most significant factors affecting flower production were tree diameter and width of tree canopy. Cultivation efforts being made to improve the production of kenanga flower is by pruning, fertilizing, flowering routine and retrieval or removal of kenanga fruit.
\end{abstract}

Keywords: Cananga odorata f. macrophylla, essential oil, cultivation, Blitar

\section{PENDAHULUAN}

Kenanga jawa (Cananga odorata f. macrophylla) merupakan tumbuhan tropis dan sub tropis yang tumbuh dengan baik pada curah hujan 700 - $5.000 \mathrm{~mm} /$ tahun (Parrotta 2009). Pada umumnya sebaran tumbuh genus Cananga ini adalah di dataran rendah sampai pada ketinggian $1.200 \mathrm{~m} \mathrm{dpl}$. Khusus untuk $C$. odorata sebaran tumbuh di dataran rendah yang lembab dengan sedikit periode kering (LaFrankie 2010). Secara geografis sebaran $C$. odorata meliputi Indonesia, Malaysia, Myanmar bagian selatan, Filipina dan Australia bagian utara (Parrotta 2009). Kenanga yang tumbuh di Indonesia adalah kenanga dari forma macrophylla. Ciri-ciri dari C. odorata f. macrophylla adalah dapat tumbuh besar dengan tinggi pohon mencapai 30 meter dan diameter hingga 1 meter. Di Pulau Jawa, C. odorata f. macrophylla tersebar di Blitar, Boyolali, Kuningan, Cirebon dan Banten (Hobir et al. 1990).

Kenanga jawa memiliki produk bukan kayu yang memiliki nilai jual tinggi (Sunanto 1993). Produk

\footnotetext{
${ }^{1}$ Mahasiswa Pascasarjana Program Studi Silvikultur Tropika, Sekolah Pascasarjana IPB

* Penulis korespondensi:

e-mail: hpropantoko@gmail.com

2 Dosen Departemen Silvikultur, Fakultas Kehutanan Institut Pertanian Bogor
}

tersebut adalah bunga dan produk turunannya adalah minyak kenanga (java cananga oil). Minyak kenanga digunakan sebagai bahan parfum, flavor, obat-obatan (Pujiarti et al. 2015), bahan baku produk kecantikan dan antioksidan (Utomo et al. 2013).

Pada tahun 1980-an Indonesia mengekspor minyak kenanga sebesar 50 ton per tahun (Hobir et al. 1990), namun pada tahun 2016 ekspor minyak kenanga hanya sebesar 3-5 ton (DAI 2017). Penurunan ini terjadi salah satunya dikarenakan oleh peremajaan (perbanyakan) pohon kenanga (Hobir et al. 1989). Penurunan peremajaan pohon mengakibatkan produksi bunga kenanga tidak dapat memenuhi pasokan bunga yang dibutuhkan oleh industri pengolahan minyak, sehingga industri pengolahan minyak juga mengalami penurunan. Hobir et al. (1990) melaporkan terjadi penurunan industri ini dari yang sebelumnya berjumlah 14 unit yang beroperasi di daerah Cirebon dan Kuningan menurun menjadi 7 unit pada tahun 1988. Berbeda dengan Cirebon dan Kuningan, Blitar sebagai salah satu produsen bunga kenanga masih bertahan sampai saat ini. Budidaya kenanga di Blitar tersebar di 16 kecamatan (Distan Blitar 2017).

Secara umum kenanga dibudidayakan di pekarangan (Hobir et al. 1990). Dalam budidaya kenanga, hal penting yang harus dilakukan adalah menjaga produksi bunga. Upaya-upaya ini mungkin telah dimiliki oleh masyarakat yang melakukan budidaya sejak lama. Untuk mengatahui upaya-upaya atau teknik budidaya tersebut, perlu 
dilakukan penelitian terhadap budidaya kenanga. Tujuan dari penelitian ini adalah mengetahui upaya masyarakat melestarikan kenanga jawa dan menganalisis produktivitas bunga kenanga jawa di Kabupaten Blitar.

\section{METODE PENELITIAN}

\section{Waktu dan Tempat}

Penelitian dilakukan mulai dari September 2017 sampai dengan Januari 2018. Lokasi penilitian meliputi desa-desa di 3 kecamatan (Kecamatan Kademangan, Kecamantan Sanankulon dan Kecamatan Ponggok) yang berada di Kabupaten Blitar. Ketiga kecamatan tersebut merupakan kecamatan penghasil bunga kenanga tertinggi di Kabupaten Blitar.

\section{Alat dan Bahan}

Alat yang digunakan dalam penelitian ini adalah kuisioner, tallysheet, meteran pita, hipsometer dan alat tulis. Bahan yang digunakan dalam penelitian ini adalah data petani kenanga dari Dinas Pertanian Kabupaten Blitar.

\section{Metode Penelitian}

Lingkup dari penelitian ini adalah mengetahui kondisi budidaya kenanga jawa di Blitar yang meliputi sebaran umur kenanga, upaya-upaya budidaya yang dilakukan masyarakat dan produktivitas bunga. Pengambilan data ini dilakukan dengan wawancara dan observasi lapangan. Metode wawancara merupakan proses memperoleh keterangan untuk tujuan penelitian dengan cara tanya jawab sambil bertatap muka antara pewawancara dan responden dengan atau tanpa pedoman wawancara (Bungin 2013).

Wawancara dilakukan terhadap responden dengan cara insidental. Pemilihan responden secara insidental adalah siapa saja yang secara kebetulan ditemui oleh peneliti sesuai dengan indikator yang ditetapkan oleh peneliti (Sugiyono 2013). Indikator dari penetapan responden adalah masyarakat yang memiliki pohon kenanga jawa (melakukan budidaya kenanga jawa).

Observasi lapangan dilakukan dengan mengukur pohon kenanga secara langsung. Pengukuran ini dilakukan pada pohon kenanga yang dimiliki oleh responden wawancara. Data pengukuran struktur pohon meliputi tinggi total pohon, tinggi bebas cabang pohon, diameter setinggi dada $(130 \mathrm{~cm})$, tebal tajuk dan luas tajuk pohon.

\section{Teknik Pengambilan Sampel}

Pengambilan sampel masyarakat untuk diwawancarai dilakukan melalui purposive dan acak dengan kuota. Unit contoh dari penelitian ini adalah masyarakat. Masyarakat yang dimaksud di sini adalah unit rumah tangga yang berprofesi petani maupun lainnya yang melakukan budidaya kenanga. Masyarakat yang digunakan dalam penelitian ini adalah satuan atau unit ekonomi, yaitu semua keluarga dan anggotanya dalam satu rumah (Penny dan Ginting 1984). Berdasarkan data dari Distan Kabupaten Blitar (2017), populasi pohon kenanga tersebar pada 16 kecamatan. Dari 16 kecamatan tersebut akan diambil 3 kecamatan dengan produksi bunga kenanga terbanyak. Kecamatan Ponggok, Kademangan, dan Sanankulon adalah daerah yang memiliki produksi bunga kenanga terbanyak (Dinas Pertanian Kabupaten Blitar 2017). Dari 3 kecamatan tersebut,akan diambil sampel tiap kecamatan dengan jumlah sampel per kecamatan sesuai porsi jumlah petani kenanga di setiap kecamatan. Besarnya sampel dalam penelitian ini ditentukan dengan rumus Slovin sebagai berikut:

$$
n=\frac{N}{1+N e^{2}}
$$

$$
\begin{aligned}
& \text { Keterangan : } \\
& \mathrm{N}=\text { jumlah sampel } \\
& \mathrm{N} \quad=\text { jumlah populasi (masyarakat } \\
& \text { pembudidaya kenanga jawa) } \\
& \text { e } \quad=\text { tingkat kesalahan (0.15) }
\end{aligned}
$$

Berdasarkan perhitungan Slovin, didapatkan sampel sebanyak 36 petani. Dari sampel 36 petani, diambil sampel setiap kecamatan dengan jumlah sesuai proporsi jumlah sebaran populasi yang ada. Berdasarkan proporsi jumlah petani kenanga setiap kecamatan, maka diperoleh jumlah sampel setiap kecamatan seperti yang ada pada Tabel 1.

Sampel untuk observasi struktur pohon diambil dari pohon milik responden yang diwawancarai pada pengambilan data wawancara. Jumlah pohon yang diukur adalah semua pohon yang dimiliki oleh responden.

\section{Pengolahan Data}

Data yang diperoleh dari wawancara dan observasi lapangan selanjutnya akan dianalisis secara deskriptif dan dilakukan pengujian dengan uji regresi. Analisis secara deskriptif dilakukan pada data budidaya kenanga jawa. Uji regresi dilakukan pada data produktivitas bunga dan data struktur pohon.

\section{HASIL DAN PEMBAHASAN}

Responden dari survei ini memiliki variasi umur dari 31 sampai dengan 80 tahun dengan rata-ratanya adalah 59 tahun. Berdasarkan jenis kelamin, responden yang berjenis kelamin laki-laki sebesar $52.8 \%$ dan perempuan sebesar $47.2 \%$. Tingkat pendidikan responden mulai dari tidak sekolah sampai dengan sekolah menengah atas dan

Tabel 1 Jumlah sampel/responden wawancara

\begin{tabular}{clccc}
\hline No & Kecamatan & $\begin{array}{c}\text { Jumlah } \\
\text { petani (RT) }\end{array}$ & $\begin{array}{c}\text { Jumlah petani per kec dibandingkan } \\
\text { dengan total 3 kecamatan (\%) }\end{array}$ & $\begin{array}{c}\text { Jumlah sampel/responden per } \\
\text { kecamatan (RT) }\end{array}$ \\
\hline 1 & Kademangan & 29 & $14 \%$ & 5 \\
2 & Sanankulon & 34 & $17 \%$ & 6 \\
3 & Ponggok & 139 & $69 \%$ & 25 \\
\hline
\end{tabular}


rata-rata adalah lulusan sekolah dasar. Keseluruhan responden melakukan budidaya di pekarangan. Jumlah kepemilikan pohon setiap rumah tangga adalah $72.22 \%$ responden memiliki 1 sampai dengan 3 pohon, sebanyak $25 \%$ responden memiliki 4 sampai dengan 7 pohon dan sebesar $2.78 \%$ yang memiliki pohon di atas 7 pohon.

\section{Budidaya Kenanga}

Berdasarkan survei, sebesar $66.7 \%$ responden melakukan peremajaan tanaman dan sebanyak $33.7 \%$ tidak melakukan peremajaan. Peremajaan dilakukan dengan menanam bibit yang diperoleh dari cabutan alam dan memelihara bibit yang tumbuh secara alami di pekarangan. Bibit cabutan alam merupakan bibit yang tumbuh secara alami di sekitar pohon kenanga. Semua responden belum pernah melakukan peremajaan dengan menggunakan bibit yang berasal dari penyemaian benih secara terencana. Keberadaan bibit cabutan alam merupakan sumber utama dari peremajaan pohon kenanga.

Pemeliharaan tanaman merupakan upaya dari masyarakat pembudidaya untuk meningkatkan atau mempertahankan produktivitas suatu tanaman. Dari hasil wawancara, $72.2 \%$ masyarakat melakukan pemeliharaan pohon kenanga. Masyarakat beranggapan bahwa dengan pemeliharaan mereka akan memperoleh hasil panen bunga yang lebih besar. Pemeliharaan yang dilakukan dikatagorikan seperti pada Gambar 1.

Setelah penanaman dengan bibit cabutan, tanaman dipelihara oleh masyarakat. Pada umur 1 sampai dengan 3 tahun dilakukan perundukan pada cabang plagiotrop bagian bawah. Perundukan ini ditujukan untuk membuat percabangan tumbuh kesamping dan kebawah. Cabang yang tumbuh kesamping dan cenderung ke bawah akan memudahkan dalam pemanenan bunga. Pohon mulai berbunga pada umur 4 - 5 tahun. Pada masa ini masyarakat melakukan pemangkasan (top pruning) dan pemupukan lanjutan. Pemangkasan ini merupakan teknik pemangkasan dengan memotong atau membuang bagian ujung tunas, dan secara khusus dilakukan pada ujung tunas vertikal utama. Pemangkasan ini dalam istilah lokal di Blitar adalah punggel. Tujuan dari pemangkasan adalah untuk menghambat pertumbuhan ke atas, meningkatkan produksi buah. Hal ini seperti yang diujicobakan oleh Moura et al. (2016) pada tanaman Physalis peruviana dimana tanaman percobaan yang dipangkas batangnya mengalami peningkatan pembungaan.

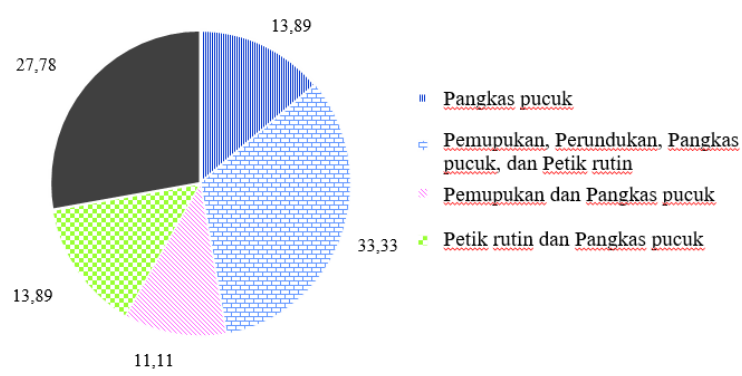

Gambar 1 Diagram lingkar pemeliharaan pohon kenanga jawa ( $C$. odorata f. macrophylla). Nilai dalam satuan persen $(\%)$
Pemangkasan pucuk cukup satu kali dilakukan, yaitu saat tinggi total pohon mencapai 5 - 6 meter. Tinggi total tersebut diperkirakan memiliki umur 4 - 6 tahun. Pemangkasan biasanya dilakukan saat musim hujan. Pada saat musim hujan, pertumbuhan vegetatif lebih cepat. Hal ini ditandai dengan pertumbuhan cabang plagiotrop cenderung lebih cepat. Menurut responden pohon yang relatif pendek dengan percabangan yang melebar memudahkan proses pemanenan dan produksi bunga semakin tinggi. Menurut Mansur (komunikasi personal), pemangkasan pucuk menjadikan pohon mempertahankan cabang-cabang yang tumbuh ke samping, sedangkan yang tidak dilakukan pemangkasan pucuk akan mengalami pengguguran cabang-cabang khususnya cabang yang berada paling bawah.

Berdasarkan wawancara yang dilakukan, pemupukan dapat meningkatkan produksi bunga. Pupuk yang digunakan adalah pupuk organik dan kimia. Pupuk organik yang dipakai adalah pupuk kandang yang langsung didapat dari kandang milik masing-masing keluarga petani. Sebesar $61.1 \%$ responden memiliki ternak di pekarangan belakang. Ternak yang mereka pelihara adalah sapi, kambing dan/atau ayam. Kotoran dari ternak digunakan untuk pemupukan pohon kenanga. Bagi responden yang tidak memiliki ternak tidak melakukan pemupukan dengan pupuk kandang, namun mereka mengumpulkan bahan organik (serasah) yang ada di sekitar pekarangan. Pupuk kimia yang digunakan adalah pupuk urea. Pupuk urea diaplikasikan dengan menggali di beberapa titik di sekitar pohon. Berdasarkan pengalaman responden, pupuk urea dapat meningkatkan pertumbuhan pohon kenanga. Informasi ini sesuai dengan Havlin et al. (1999) bahwa nitrogen pada pupuk urea dapat meningkatkan pertumbuhan vegetatif tanaman. Namun penggunaan pupuk kimia urea juga dapat menyebabkan pohon lebih rentan terhadap angin kencang. Menurut pengalaman mereka, pohon kenanga yang dipupuk dengan pupuk urea mudah rebah saat ada angin kencang.

Menurut Mansur (2010) pemupukan lanjutan saat pemeliharaan tanaman hutan dapat memberikan asupan makanan baru bagi tanaman dan mempercepat pertumbuhan. Mansur (2010) menyatakan bahwa pada tanaman sengon (Albasia falcataria) yang diberikan pemupukan lanjutan dapat dipanen pada umur 5 tahun dan pada sengon yang tidak diberikan pupuk membutuhkan waktu 7-10 tahun untuk sampai waktu panen.

Responden menyatakan bahwa pemanenan bunga secara rutin dapat mempertahankan pembungaan yang lebat. Pemanenan bunga secara rutin yang dimaksud adalah pemetikan bunga kenanga pada bunga yang sudah masak. Bunga dianggap masak pohon adalah bunga yang berwarna hijau kekuningan dan memiliki aroma yang wangi. Pemanenan bunga secara rutin akan menghambat timbulnya buah. Pemunculan buah kenanga akan menghambat produksi bunga baru. Apabila pemetikan bunga secara rutin sudah dilakukan, namun buah masih muncul, tindakan yang dilakukan oleh masyarakat adalah memetik buah yang telah tumbuh. Berdasarkan Salisbury dan Ross (1995) pertumbuhan generatif buah akan menghambat pertumbuhan pada organ lainya. Fotosintat 
yang dihasilkan dari proses fotosintesis akan difokuskan pada pertumbuhan buah melalui jaringan floem.

Berdasarkan uraian di atas, teknik budidaya kenanga yang dilakukan oleh responden yang tersebar di 3 kecamatan memiliki tahapan-tahapan pada setiap umur pohon. Menurut mereka teknik ini merupakan langkah yang dilakukan untuk memperoleh panen bunga yang besar dan secara teknis lebih mudah dalam melakukan pemanenan bunga. Tahapan-tahapan tersebut diringkas seperti pada Tabel 3 .

\section{Sebaran Umur Pohon Kenanga di Blitar}

Sebaran umur pohon berdasarkan hasil wawancara adalah antara 0.5 tahun sampai dengan 80 tahun. Menurut responden pohon kenanga akan mulai berbunga pada umur 4 tahun. Pohon kenanga umur 4 sampai 10 tahun berada pada tahap produksi bunga, namun masih relatif kecil jumlahnya. Usia di atas 10 tahun pohon kenanga sudah mulai berbunga lebat. Pada usia ini (>10 tahun) pohon kenanga memiliki nilai ekonomi yang tinggi. Kerapatan pohon dan rata-rata produksi bunga pada setiap pengelompokan umur dapat dilihat pada Gambar 2 .

Menurut Hilwan dan Irfani (2018) nilai kerapatan menggambarkan kaidah umum struktur tegakan hutan untuk menilai kelestarian jenis. Kerapatan pohon berdasarkan umur pada Gambar 2 menggambarkan bentuk seperti huruf "J" yang artinya kerapatan pohon semakin tinggi pada setiap bertambahnya umur pohon.

Hal ini menunjukkan bahwa kerapatan pohon yang dimiliki masyarakat sebagian besar berusia produktif dan populasi tanaman muda relatif sedikit. Hal demikian menunjukan kelestarian pohon masa akan datang tergolong rendah.

Berdasarkan Gambar 2 bahwa pohon pada kelompok umur 0 sampai 3 tahun belum berbunga. Tingkat pertumbuhan pada kelompok ini masih terfokus pada pertumbuhan vegetatif, seperti pertumbuhan tinggi dan

Tabel 3 Tahapan budidaya kenanga (Cananga odorata f. macrophylla) di Blitar

\begin{tabular}{|c|c|c|}
\hline $\begin{array}{l}\text { Umur } \\
\text { pohon } \\
\text { (tahun) }\end{array}$ & $\begin{array}{c}\text { Tahapan } \\
\text { budidaya }\end{array}$ & Teknik \\
\hline \multirow[t]{2}{*}{0} & Penanaman & Bibit dari cabutan alam \\
\hline & $\begin{array}{l}\text { Pemupukan } \\
\text { awal }\end{array}$ & $\begin{array}{l}\text { Pemupukan dengan pupuk } \\
\text { kandang pada lubang tanam. } \\
\text { Pupuk yang digunakan kurang } \\
\text { lebih } 2 \mathrm{~kg}\end{array}$ \\
\hline $1-3$ & $\begin{array}{l}\text { Perundukan } \\
\text { pada cabang } \\
\text { plagiotrop }\end{array}$ & $\begin{array}{l}\text { Cabang dirundukan dengan } \\
\text { cara menarik menggunakan } \\
\text { tali dadung dan diikatkan } \\
\text { pada pangkal batang pohon } \\
\text { itu sendiri }\end{array}$ \\
\hline \multirow[t]{2}{*}{$4-5$} & $\begin{array}{l}\text { Pemangkasan } \\
\text { pucuk }\end{array}$ & Pemangkasan pucuk tajuk \\
\hline & $\begin{array}{l}\text { Pemupukan } \\
\text { lanjutan }\end{array}$ & $\begin{array}{l}\text { Penumpukan bahan organik } \\
\text { (pupuk kandang dan kompos) } \\
\text { di sekitar pangkal batang dan } \\
\text { pemupukan dengan pupuk } \\
\text { urea }\end{array}$ \\
\hline \multirow[t]{2}{*}{$>4$} & $\begin{array}{l}\text { Pemanenan } \\
\text { bunga }\end{array}$ & $\begin{array}{l}\text { Pemanjatan dan dengan } \\
\text { menggunakan galah }\end{array}$ \\
\hline & $\begin{array}{l}\text { Pengambilan } \\
\text { buah }\end{array}$ & $\begin{array}{l}\text { Pemanjatan dan dengan } \\
\text { menggunakan galah }\end{array}$ \\
\hline
\end{tabular}

diameter batang. Perkembangan pada tahap generatif dimulai pada kelompok umur 4 sampai 10 tahun. Pada kelompok umur ini, pohon mulai berbunga meskipun nilainya belum tinggi, yaitu $175.5 \mathrm{~kg}$ per pohon per tahunnya. Produksi bunga akan semakin besar saat memasuki umur 11 tahun. Pada umur 11 tahun ke atas, rata-rata produksi bunga menvapai $381 \mathrm{~kg}$ per pohon per tahun.

Pertumbuhan diameter pada kelompok umur 0 sampai 3 tahun adalah $4.56 \mathrm{~cm} /$ tahun. Pertumbuhan diameter pada kelompok umur 4 sampai 10 tahun yaitu $5.68 \mathrm{~cm} /$ tahun, sedangkan pertambahan diameter pada usia produktif untuk berbunga yaitu pada kelompok umur di atas 10 tahun adalah $0.57 \mathrm{~cm} /$ tahun. Nilai ini menunjukan bahwa pada kelompok umur 0 sampai 3 tahun pohon kenanga mengalami pertumbuhan yang besar dibandingkan dengan usia di atas 10 tahun dan pada usia di atas 10 tahun dan pertumbuhan paling besar berada pada pertumbuhan generatif yaitu produksi bunga. Ryan et al. (1997) menyatakan bahwa pertumbuhan tanaman pohon awalnya akan lambat, lalu meningkat ketika luas daun berkembang dan kemudian akan menurun.

\section{Produksi Bunga}

Berdasarkan wawancara yang dilakukan bahwa pemanenan bunga dilakukan setiap 14 hari sekali atau 2 kali per bulan. Pohon kenanga berbunga sepanjang tahun, sehingga dalam setahun bunga dipanen sebanyak 24 kali. Berdasarkan hasil wawancara dan analisis data observasi, bahwa produksi bunga berbeda-beda. Perbedaan produksi bunga ini terjadi pada satu pohon dalam musim yang berbeda dan perbedaan produksi bunga pada setiap pohon. Perbedaan produksi dalam satu pohon pada musim yang berbeda dipengaruhi oleh iklim dan cuaca, sedangkan perbedaan produksi bunga pada setiap pohon dipengaruhi oleh faktor-faktor antara lain umur pohon, dimensi pohon, tebal tajuk, luas penampang tajuk dan pemeliharaan yang dilakukan oleh masyarakat.

Berdasarkan musim, produksi bunga kenanga pada musim kemarau lebih besar dibandingkan dengan saat musim penghujan. Menurut petani dan pengepul, panen pada musim kemarau bisa mencapai dua kali lipat dari panen pada musim penghujan. Rendahnya produksi

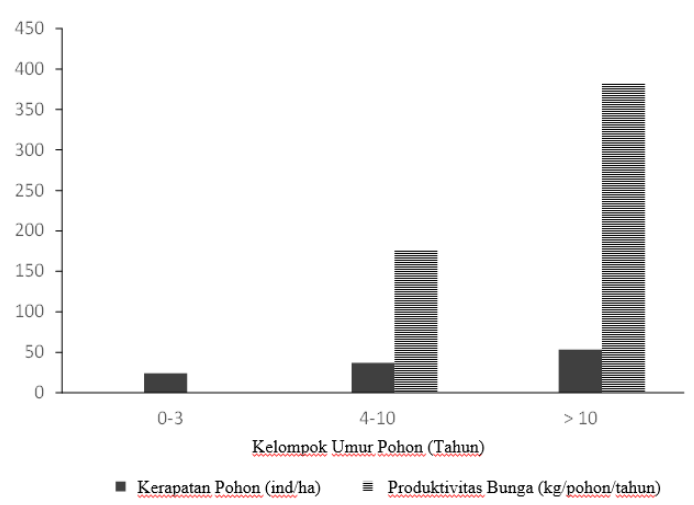

Gambar 2 Kerapatan pohon dan rata-rata produksi bunga kenanga jawa (Cananga odorata f. macrophylla) pada setiap pengelompokan umur 
bunga saat musim penghujan diperkirakan oleh karena rontoknya bunga ketika masih kuncup yang disebabkan oleh angin dan pertumbuhan pohon yang cenderung lebih besar pada pertumbuhan pucuk daun. Penggunaan fotosintat pada pertumbuhan vegetatif yaitu pada pucuk daun akan menghambat pertumbuhan generatif yang terjadi pada tumbuhan. Hasil uji regresi berganda pada faktor-faktor yang mempengaruhi produktivitas bunga dipaparkan pada Tabel 2.

Berdasarkan Tabel 2, faktor yang memiliki pengaruh pada produksi bunga adalah diameter batang dan luas tajuk, sedangkan faktor umur, tinggi total dan tebal tajuk tidak berpengaruh nyata pada produksi bunga. Faktor diameter batang dan luas tajuk memiliki pengaruh positif pada produksi bunga. Semakin tinggi nilai kedua faktor tersebut maka produksi bunga semakin tinggi.

\section{Produksi bunga berdasarkan umur pohon}

Berdasarkan uji t pada Tabel 2 di atas, faktor umur tidak memiliki pengaruh pada produksi bunga. Namun secara deskriptif antara umur dan produksi bunga cenderung memiliki pengaruh. Selain itu, informasi yang diperoleh dari masyarakat, bahwa semakin tua umur pohon kenanga maka semakin tinggi produksi bunganya. Produksi bunga berdasarkan struktur tegakan pohon

Diameter pohon memiliki hubungan yang nyata dengan produksi bunga. Tinggi total pohon memiliki hubungan yang tidak nyata dengan produksi bunga.

Tabel 2 Uji t faktor bebas pada faktor tidak bebas yaitu produksi bunga kenanga (Cananga odorata f. macrophylla)

\begin{tabular}{lc}
\hline Faktor Bebas & Rata-rata \\
\hline Umur & $16.62^{\text {tn }}$ \\
Diameter batang & $36.89^{*}$ \\
Tinggi total & $11.48^{\text {tn }}$ \\
Tebal tajuk & $4.91^{\text {tn }}$ \\
Luas tajuk & $45.71^{*}$ \\
\hline${ }^{\text {tn }}$ menandakan faktor bebas tidak berpengaruh \\
nyata pada faktor terikat \\
menandakan faktor bebas berpengaruh nyata \\
pada faktor terikat
\end{tabular}

(a)

Kurva regresi antara Diameter Pohon dengan Produksi Bungaper tahun

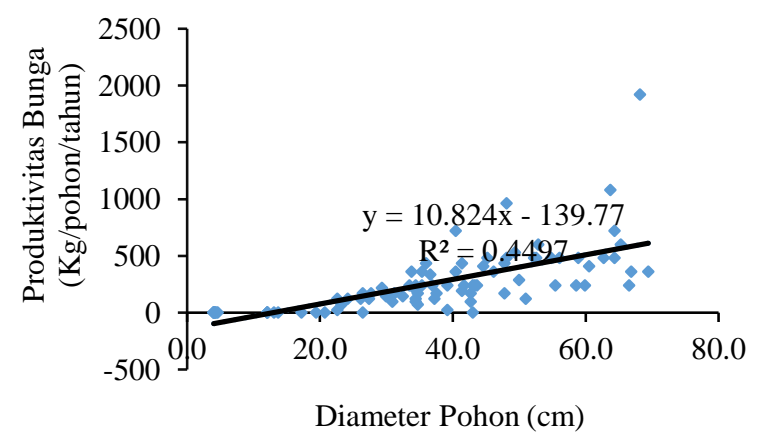

Tebal tajuk juga tidak berpengaruh nyata pada produksi bunga. Berdasarkan informasi yang didapat, bahwa petani melakukan pemangkasan pucuk pohon. Pemangkasan ini dilakukan untuk memudahkan pemetikan bunga. Pemangkasan ini tentunya mengakibatkan tinggi total pohon dan tebal tajuk tidak tumbuh secara alami. Keragaman tinggi total pohon dan tebal tajuk dipengaruhi oleh pemeliharaan masyarakat pembudidaya.

Berdasarkan uji regresi pada Gambar 3a, semakin tinggi nilai diameter batang maka semakin besar juga nilai produktivitas bunga. Faktor luas tajuk juga memiliki hubungan yang nyata terhadap produktivitas bunga. Hubungan antara peubah luas tajuk dan produksi bunga bernilai positif, Gambar 3b menunjukan bahwa semakin meningkat luas tajuk maka semakin meningkat jumlah produksi bunga. Luas tajuk berhubungan dengan jumlah daun. Semakin besar nilai luas tajuk, maka kemungkinan jumlah daun akan semakin banyak juga. Semakin banyak daun pada suatu tanaman akan meningkatkan pertumbuhan tanaman tersebut (Assmann 1970). Pertumbuhan diartikan dari penambahan biomassa (Ryan et al. 1997). Pada penelitian ini penambahan biomassa ditunjukkan dari jumlah produksi bunga yang dihasilkan oleh pohon kenanga.

\section{SIMPULAN DAN SARAN}

\section{Simpulan}

Teknik budidaya yang dilakukan oleh masyarakat Blitar mulai dari penanaman meliputi 1) penanaman dengan menggunakan bibit cabutan, 2) perundukan pada cabang plagiotrop pada umur pohon 1-3 tahun, 3) pemangkasan pucuk dan pemupukan lanjutan pada umur 4-5 tahun, serta 5) pemetikan bunga dengan menggunakan galah dan pemanjatan pada umur pohon 4 tahun ke atas.

Produksi bunga pada pohon kenanga mulai pada tahun ke 4. Pada kelompok umur pohon 4-10 tahun, ratarata produksi bunganya adalah $175.5 \mathrm{~kg}$ per pohon per tahun. Rata-rata produksi bunga tertinggi terdapat pada kelompok umur di atas 11 tahun. Kelompok ini rata-rata

(b)

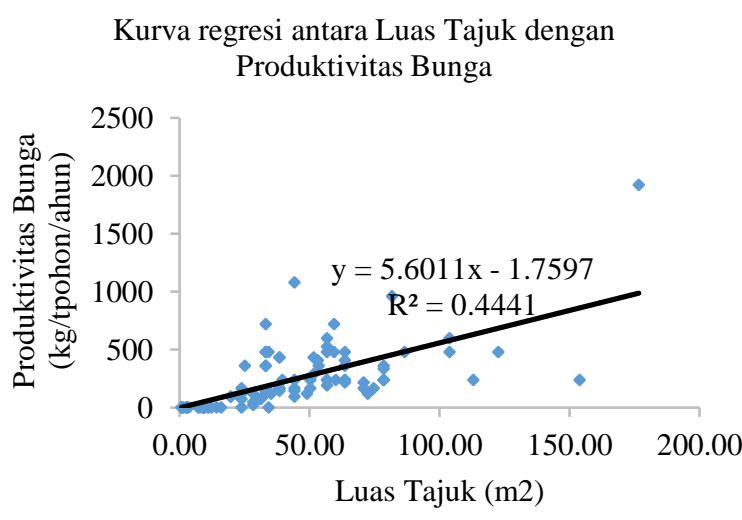

Gambar 3 Kurva regresi antara faktor bebas dengan faktor tidak bebas (a) tinggi total pohon dengan produksi bunga dan (b) luas tajuk dengan produksi bunga kenanga (Cananga odorata f. macrophylla). 
produksi bunga sebesar $381 \mathrm{~kg}$ per pohon per tahun. Produksi bunga kenanga secara signifikan dipengaruhi oleh diameter batang dan luas tajuk. Semakin tinggi nilai 2 faktor tersebut, nilai produksi bunga juga semakin meningkat.

\section{Saran}

Peyiapan benih sebagai bibit untuk peremajaan perlu dilakukan untuk memperoleh sumber bibit unggul. Keberadaan upaya budidaya untuk mempertahankan produksi bunga kenanga di Kabupaten Blitar sebaiknya dilakukan pendampingan dari para pihak kepada masyarakat untuk peningkatan produksi bunga.

\section{DAFTAR PUSTAKA}

Assman E. 1970. The Principles of Forest Yield Study. Oxford (UK): Pergamon Press

Bungin MB. 2013. Metodologi Penelitian Sosial dan Ekonomi. Jakarta (ID): Prenamedia Group.

[DAI] Dewan Atsiri Indonesia. 2017. Indonesian Essential Oil Output in 2014-2016. Jakarta (ID):DAI.

[Distan Kabupaten Blitar] Dinas Pertanian Kabupaten Blitar. 2017. Daftar Sebaran Pohon Kenanga di Kabupaten Blitar Tahun 2016. Blitar (ID): Distan Kabupaten Blitar.

Havlin JL, Beaton JD, Tisdale SL, Nelson WL. 1999. Soil Fertility and Fertilizer. New Jersey (US): Prentice Hall

Hilwan I, Irfani E. 2018. Pola penyebaran dan regenerasi jenis saninten (Castanopsis argentea) di resort Selabintana, Taman Nasional Gunung Gede Pangrango. Jurnal Silvikultur Tropika. 9(1):53-59.

Hobir, Tarigans DD, Hamid A. 1989. Minyak atsiri (kenanga, mentha, serai wangi). LITRO. 5(1):1223.
Hobir, Ellyda AW, Anggreini, Makmun. 1990. Kenanga dan ylang-ylang. LITTRO. 6(1):30-37

LaFrangkie JV. 2010. Trees of Tropical Asia-An Illustrated Guide to Diversity. Philippines (PH): Black Tree Publication Inc.

Mansur I. 2010. Teknik Silvikultur untuk Reklamasi Lahan Bekas Tambang. Bogor (ID): SEAMEO BIOTROP.

Moura PHA, Coutinho G, Pio R, Bianchini FG, Curi PN. 2016. Plastic covering, planting density, nad pruning in the production of cape gooseberry (Physalis peruviana L.) in subtropical region. Caatinga Mossoro. 29(2):367-374.

Parrotta JA. 2009. Cananga odorata. Enzyklopadie der Holzgewachse. 54:01-10.

Penny DH, Ginting M. 1984. Pekarangan, Petani dan Kemiskinan. Yogyakarta (ID): Gajah Mada University Press.

Pujiarti R, Widowati TB, Kasmudjo, Sunarta S. 2015. Kualitas, komposisi kimia dan aktivitas antioksidan minyak kenanga (Cananga odorata). Jurnal Ilmu Kehutanan. 9(1):3-11.

Ryan MG, Bingkley D, Fownes JH. 1997. Age-related decline and productivity:pattern and process. Advances in Ecological Research. 27:214-252.

Salisbury FB, Ross CW. 1995. Fisiologi Tumbuhan. Edisi ke-4. Lukman DR, Sumaryono, penerjemah; Niksolihin S, editor. Bandung (ID): Penerbit ITB. Terjemahan dari: Plant Physiology, 4th edition.

Sugiyono. 2013. Metode Penelitian Kuantitatif, Kualitatif dan Kombinasi (Mixed Methodes). Bandung (ID): Penerbit Alfabeta.

Sunanto H. 1993. Budidaya Kenanga. Yogyakarta (ID): Penerbit Kanisius.

Utomo AR, Retnowati R, Juswono UP. 2013. Pengaruh konsentrasi minyak kenanga (Cananga odorata) terhadap aktivitasnya sebagai antiradikal bebas. Kimia Student Journal. 1(2):264-268. 